\title{
Introduction: the Development of Youth Policies in Europe in Past Decades
}

\author{
Tom Chevalier \\ Université de Rennes, IEP de Rennes, CNRS, Arènes, France \\ tom.chevalier@sciencespo.fr \\ Patricia Loncle \\ EHESP/Arènes, Rennes, France \\ Patricia.Loncle@ehesp.fr
}

Youth policies in Europe represent an issue quite difficult to grasp: according to countries and to territories, their target, their content and their resources appear to vary dramatically, although they have been developed more or less in all European national and infra national contexts during the last decades. Yet, little knowledge has been gathered so far to describe and analyze the evolution of these policies. This special issue will explore the recent trends that influence youth policies in Europe: the way they are framed, implemented and, possibly, assessed. The development of youth policies in Europe may be analysed as the result of three concurrent processes, which take place at different levels of policymaking.

Firstly, the rise of European youth policies under the leadership of the European Commission and the Council of Europe, in particular since the 2001 White Paper "A new impetus for European youth". Indeed, although the European institutions do not have competences that would apply in a mandatory way to the Member States, they play a very significant role in the field of youth policies. This role is embodied both by the Council of Europe, which has been working on youth issues since the 196os, and by the European Commission, which has taken on these tasks since 1986 and has launched the "Youth for Europe" Programme. Of course, these two institutions have their own, only partially overlapping, agendas, objectives and values (Boetzelen, 2017). Nevertheless, they have been working together since 1998 through the creation of the Youth Partnership, the joint organisation of training sessions, the publication of a specialized magazine (the Coyote magazine), the 
production of toolkits for youth workers and the support of the emergence of research on youth issues (Schild, 2013). The regular organization of meetings among decisionmakers, professionals and researchers on youth issues in Europe makes it possible to gradually develop common principles and guidelines on what could constitute the main lines of public intervention for young people in Europe. The recently held Third Convention On Youth Work organised by the German Ministry for Family Affairs, Senior Citizens, Women and Youth on the occasion of Germany's joint presidency of the Council of the European Union and the Council of Europe - which brought together more than a thousand people to draw up a joint declaration - is a good illustration of this process (Final declaration, 2020). These institutions are thus participating in a process of "horizontal Europeanisation" (Featherstone and Radaelli, 2003). In the wake of the 2007 economic crisis, the European Council has taken this Europeanization even further by adopting the "European Youth Guarantee" in 2013: this represented the first policy targeted at unemployed youth (the so-called "NEET s") with a substantial budget, provided by both the Youth Employment Initiative and the European Social Fund.

Secondly, youth policies have also sought to address the problems of young people at the national level. In fact, "youth", as a period of life, has emerged due to the development of education and to the increase of youth unemployment and difficulties in entering the labour market and accessing employment (Buchmann and Kriesi 2011; Cavalli and Galland 1995). As a result, youth unemployment has steadily increased since the 1970s, along with related social difficulties such as youth poverty and precarity (Antonucci, Hamilton, and Roberts 2014). This long-term trend has concentrated economic and social vulnerability on youth (O'Reilly et al. 2019), leading some authors to argue that young people now constitute a "new social risk group" (Bonoli 2005; Knijn 2012). In response to such a phenomenon, youth policies have shifted towards addressing education and employment issues. Since these issues have been put on the political agenda, thereby holding politicians accountable, public policies have developed at the national level. The 2007 crisis, and the current pandemic of COVID-19, has pushed policymakers to take this path as youth unemployment and poverty has risen even more in these turbulent times (Bell and Blanchflower 2011).

As a result, the agenda-setting of youth policies in European countries has tended to be influenced by challenges that transcend the traditional definition of what is usually referred to as "youth policies" (i.e., policies targeting young people in the field of non-formal education) and are more generally related to welfare states or economic considerations. Many types of policy instruments have therefore been used by policymakers to cope with these new 
issues: to begin with, a range of employment policies has been implemented to fight youth unemployment and promote access to employment. These active labour market policies differ in their "pro-market orientation" and their level of investment in human capital (Bonoli 2010): employment incentives (such as exemptions from social contributions), direct job creation in the public sector, labour market deregulation, employment assistance, vocational training, or incentive reinforcement (reduction or conditionality of social benefits). In addition to employment policies, education policies have also been at the core of policy responses to youth issues. In this matter, policy instruments are very diverse (ranging from the differentiation of the education system to teacher training for instance) and may be distinguished according to their level (upper secondary, tertiary) and their skill-specificity. The latter concerns the extent to which education systems are open to employers' demands in terms of skills: where education systems are open to these demands, vocational training and apprenticeship tend to be more developed, as are "specific skills" (as opposed to "general" skills), leading to a smoother entry into the labour market, and ultimately a lower youth unemployment rate (Busemeyer 2015; Estevez-Abe, Iversen, and Soskice 2001; Müller and Gangl 2003). Furthermore, social benefits have proven to be an important means of coping with "youth transitions". Indeed, because young people as disproportionally newcomers to the labour market and at higher risk of unemployment, they are a key target group of unemployment benefits. Likewise, they are also more at risk of poverty, which makes them a considerable part of the beneficiaries of minimum income schemes and social assistance on the one hand, and housing benefits on the other. In-between childhood and adulthood, young people are in a specific situation with regards to social security systems (Jones and Wallace 1992), making family policies also a way to support them via their parents. Lastly, financial measures targeting students (such as grants or loans, and fees) are also adopted by governments as policy instruments (Garritzmann 2016). They can be deemed partly education policies (since they are linked to tertiary education enrolment) and partly social benefits (since the policy instrument used is a monetary transfer).

This leads us to the third and last of the main concurrent trends in youth policy: infranational initiatives (at regional or/and local levels), which are progressing in a context of growing decentralisation practices across European countries. Indeed, sub-national youth policies have tended to proliferate widely across Europe. Their design and implementation vary greatly according to national contexts, traditions of intervention and the decentralisation/ devolution balances adopted by each country. Within the framework of the Partispace research (Partispace.eu), three types of institutional arrangements 
were pointed out: systems that remain centralised and where the territorial levels are only levels of implementation (Bulgaria and Turkey), systems in which centralisation and decentralisation coexist (France, Germany, Sweden and the UK), and essentially decentralised systems (at the regional level in Italy and at the local level in Switzerland) (Andersonn et al., 2016). Some of these sub-national spaces have long traditions of youth work: this is particularly the case for the cities of Manchester (United Kingdom), Bologna (Italy) and Rennes (France) in our panel. Others have formalised their interventions more recently, such as Plovdiv (Bulgaria) in particular. Evidently, the local youth policies that are gradually being formalised locally have specific dimensions, whether in terms of the allocated funds, the human resources devoted to them, the type of young people involved or the issues addressed (Walther and al., 202O). Nevertheless, a trend towards convergence can be observed, particularly due to the influence of the European institutions, which tend to propose an intervention framework to the Member States and their sub-national levels. The elements of convergence include the ever-increasing importance given to the issue of employment and the fight against early school leaving, a tendency to individualise institutional support, the multiplication of "new interventions" in the form of outreach work or online youth work (Williamson, 2020).

Despite these common trends, both the framing and the type of youth policies differ quite a bit from one country to another in terms of the public problems they intend to address, the governance system they adopt, the definition of the targeted youth, the allocated resources, and the kinds of policy instruments they mobilize. As an important variety of policy instruments is concerned to cope with youth transitions, many authors have proposed different typologies in order to conceptualize such long-lasting international diversity. In the realm of education policies, scholars have distinguished different national education systems based on the importance of vocational education and training (Busemeyer 2009; Gangl 2001), the place of the private sector (Busemeyer 2015), or its levels of "standardization" and "stratification" (Allmendinger 1989). As far as employment policies are concerned, Pohl and Walther (2007) have identified different ways of activating the young unemployed depending on whether the policy diagnosis is "individualizing" or "structural" on the one hand, and whether the measure is "compensatory" or "preventive" on the other hand. All these policies structure the school-to-work transition of young people in very different ways in Europe (Hadjivassiliou et al. 2019). More generally, Walther (2006) has theorized four "youth transition regimes", based on the famous "welfare regimes" typology (Esping-Andersen 1990; Gallie and Paugam 2000): the "universalistic" regime of Nordic countries, 
the "employment-centred" regime of Continental countries such as Germany, the "liberal" regime (UK), and the "sub-protective" regime of Mediterranean countries. Lastly, Chevalier (2016) has proposed to further analyse youth policies by distinguishing education and employment policies trying to promote young people's access to employment on the one hand ("economic citizenship") and social benefits and student support delivering income support on the other ("social citizenship"). Economic citizenship policies are either "inclusive" or "selective" depending on the focus on skill formation, while social citizenship policies are either "familialized" or "individualized" depending on whether young people are considered as children or adults by the state.

The reactions of young people and of non-formal education actors to this public performance are mixed. In many instances, associative and individual actors will use the facilities provided by public authorities. Although often weak and fragmented, public youth policies partially respond to the needs of young people and youth workers. They therefore serve as a vector for action for operators who originate most often from public services or associations. Nevertheless, the content of youth policies and their adequacy with regards to the needs of young people raise questions for several reasons. First of all, these policies tend to be based on stigmatising norms with regard to young people which often serve as a repellent for target audiences (Jones, 2009; Wacquant, 2012). For example, young people are often reluctant to enter mental health care; public services are considered to be reserved for the "crazy"people; they are also often suspicious of vocational courses, which are devalued in most European countries. Secondly, they most often develop from silo approaches that limit their effectiveness (Kalala-Mabuluki and Siurala, 2019). Finally, they are often complex and young people (same as other groups of the population) do not always know what support and assistance they are entitled to (Dubois and Ludwinek, 2015). As a result of all these factors, many young people do not make use of the public assistance available to them (Vial, 2020). Beyond (or as a result of) these difficulties in designing youth policies, many young people's initiatives are developing, particularly at local level, often on the margins or even in opposition to the public authorities, and tend to organise their own actions in a wide range of fields (be it sport, the environment, protection of the most vulnerable, etc.) (Walther and al., 2019). It should be noted that these initiatives, very often fuelled by anger or a feeling of injustice (Pickard and Van de Velde, to be published), compensate for the absence of public authorities in certain areas in number of cases, particularly when it comes to the rights and needs of people in exile (recently arrived third-country immigrants regardless of their administrative status) (Loncle and Martin, 2019). 


\section{Presentation of the Articles}

The texts in this issue reflect these general developments in youth policy. The first paper of the issue deals with the general issue of youth employment. As it has gained traction and was put on the agenda of many countries, policymakers have had to implement policies that aim at fighting youth unemployment. Most of these policies stem from the institutional realm of employment policies. In her text, Maria-Eugenia Longo compares youth employment policies in four very different contexts: France, Canada, Quebec, and Argentina. Despite some similarities, she highlights the huge differences between these countries with regards to state's action/policy to promote youth employment. First, the institutional characteristics of these policies differ in terms of the problem identified (unemployment, exclusion, lack of education, labour shortage), the target group (disadvantaged, unemployed, assisted, vulnerable youth), and the main solutions proposed (employment opportunities, education and training, work experience, job search assistance). Second, the semantic analysis of policy documents reveals different implicit frames of reference. These analyses allow the author to identify the different frames of reference concerning youth employment policies, relating to different social norms. In a third part, she evaluates to what extent the countries' policies under investigation echo these norms, through the use of expert interviews.

The second paper of the issue also deals with employment policies. However, unlike the previous one which analyses their ideational logic, the article by Veronica Knize, Markus Wolf and Cordula Zabel evaluates their effects in terms of inequalities. Active labour market policies (ALMP) are part of what has been called the "social investment welfare state". Yet, the literature has emphasised the possibility of such a strategy to lead to "Matthew effects": in other words, these policies may favour the better off, hence exacerbating already existing inequalities instead of counteracting them. The authors try to address this issue by quantitatively studying the entry into different ALMP programs of 20 to 22-year-olds in Germany in 2014. They show that young people with a lower level of education or employment experience are indeed less likely to enter the best ALMP programmes, such as firm-based upskilling and employment assistance, which confirms the presence of Matthew effects. However, welfare experience during adolescence does not affect entry into these programmes: in other words, there is no Mathew effect with regards to the family of origin. Hence, while Matthew effects are confirmed concerning intra-generational inequalities, they are not as far as inter-generational inequalities are concerned. 
The third paper of the issue, written by Fransez Poisson, focuses on the circulation of ideas and initiatives in the field of youth policies. Indeed, since the emergence of public policies specifically dedicated to youth at the end of the 19th century, this field of public action has been subject to strong international exchange of ideas, which have increased significantly in recent decades. However, the circulation of ideas from one country to another, and especially the local appropriation of ideas from abroad, have not really been analysed in the field of youth policies. This is what Fransez Poisson proposes to do in this issue using the actor-network theory and the notion of transnationalization of public policies. The article looks at the way in which transfers operate by investigating the conditions of the local implementation of international initiatives.

The following paper explores the consequences of the Europeanization process described above. For Frederike Hofmann-van de Poll, it is indeed a question of considering the influences that a soft policy such as the youth strategy of the European Union may have on the effective implementation of youth policies at the local level. Although quite developed in other sectors (such as agriculture, culture, or social policies, for example), the process of Europeanisation of youth policies has so far been understudied and the study of its implementation even more so. The example of a federal state such as Germany is particularly enlightening in this respect: the 'stimuli' of the European Union are thus integrated into pre-existing broad consultation processes involving the three decision-making levels concerned with youth policies (federal, Länder, and municipal levels). Based on qualitative data, Frederike Hofmann-van de Poll analyses the way in which the various actors, and in particular municipal actors, take the guidelines of the European institutions into account in practice. While the latter seem to be well accepted because they are perceived as matching the needs of young people and youth workers, municipal actors have to deal with contexts that are sometimes extremely constrained (in terms of human and financial resources).

Axel Pohl and Morena Cuconato further investigate these links between different levels of policies but focus on the reception of these policies by young people. By comparing two municipal contexts - Frankfurt in Germany and Bologna in Italy - they analyse the way youth policies at the local level echo national policies, before going on to shed light on how young people view and receive these local initiatives. In fact, they react very differently in the two countries, leading to different forms of participation. In Italy, the city of Bologna has historically tried to promote youth participation. However, due to the crisis and budget cuts, initiatives have diminished. In Frankfurt on the contrary, the strong corporatism that defines the German welfare regime has led to relative importance of welfare and youth organizations, fuelling 
paradoxical trends. On the one hand, it has structured effective social integration for young people. On the other hand, it has led to the depoliticization of youth policies.

Isabelle Danic, Barbara Fontar, and Agnès Grimault-Leprince also consider the local level by arguing that local youth policies do influence teenagers' leisure experiences. By comparing different territorial contexts in three French regions, they propose an analysis relying on mixed methods. On the one hand, a statistical analysis allows them to show that more leisure activities are available in urban areas as well as in territories where more facilities are available. Still, some differences emerge depending on the types of facilities and activities. Then, on the other hand, the authors proceed to a qualitative interpretation of adolescents' experiences in order to seize the mechanisms at play, such as the role of sociability and peer relationships. This approach also permits to understand the inequalities of teenagers' experiences and the role of family resources, and how both interact with local policies, since teenagers from disadvantaged families tend to enjoy more leisure activities.

Still with a view to analysing implementation and echoing the previous article on the impact of European youth policies, Luca Raffini, Anna Reggiardo, and Andrea Pirni look at the influence of the third sector in the implementation of European public action. In their article, Luca Raffini, Anna Reggiardo and Andrea Pirni show how the third sector plays an innovative role in the youth field. To do so, the authors analyse the contents of the Youth Strategy and the Youth Guarantee and highlight the apparent paradigm shifts of these policies (in particular from "employment" to "activation" and "employability"). They then look at the specificities of Italian youth policies and their consequences on the incorporation of European policies. Finally, they examine how the contents of European youth policies actually meet developments already at work, especially in the fields of volunteering and social entrepreneurship. From this point of view, the third sector continues to play a leading role in youth policies through the changes it has brought about.

The last paper of the issue, from Demet Lüküslü and Andreas Walther, is dedicated to the question of youth participation and more specifically to the profiles of young people who participate in formal initiatives launched by public stakeholders. This topic appears to be of central importance at a time when the adequacy of youth policies is constantly being questioned, in terms of their capacity to respond to the needs of young people. However, the uses of youth formal participation (youth councils and other youth assemblies) have been much criticised in recent years: they are commonly accused of paternalism, denounced because of the weak effective account of young people's voices, 
and because of the low level of representation of young people willing to get involved. Andreas Walther and Demet Lüküslü have chosen to confront this dimension by asking the following question: What is it that makes young people still accept to get involved in these participation spaces today even when their structural weaknesses are well identified? By adopting a biographical perspective, they identify the key dimensions that lead to the involvement of some young people in formal participation spaces.

\section{References}

Allmendinger, J. 1989. "Educational Systems and Labor Market Outcomes." European Sociological Review 5 (2), pp. 231-50.

Andersonn, B. et al. 2016. WP2 - National Contexts Comparative Report UNIBO, Italy UGOT, Sweden. Partispace working paper D2.2.

Antonucci, L., M. Hamilton, and S. Roberts, eds. 2014. Young People and Social Policy in Europe. Dealing with Risk, Inequality, and Precarity in Times of Crisis. Basingstoke: Palgrave Macmillan.

Bell, D., and D. Blanchflower. 2011. "Young People and the Great Recession." Oxford Review of Economic Policy 27 (2), pp. 241-67.

Boetzelen, P. 2017. "Les Institutions Européennes et La Jeunesse: Rôles, Objectifs et Instruments." In L'Europe de La Jeunesse: Enjeux et Pratiques Des Politiques Publiques, ed. P. Loncle. Rennes: Presses de l'Ecole des hautes études en santé publique, pp. 8-20.

Bonoli, G. 2005. "The Politics of the New Social Policies: Providing Coverage against New Social Risks in Mature Welfare States." Policy \& politics 33(3): 431-49.

Bonoli, G. 2010. "The Political Economy of Active Labor-Market Policy." Politics \& Society 38 (4), pp. 435-57.

Buchmann, M. C., and I. Kriesi. 2011. "Transition to Adulthood in Europe." Annual Review of Sociology 37 (1), pp. 481-503.

Busemeyer, M. R. 2015. Skills and Inequality. Partisan Politics and the Political Economy of Education Reforms in Western Welfare States. Cambridge: Cambridge University Press.

Busemeyer, M.R. 20o9. "Asset Specificity, Institutional Complementarities and the Variety of Skill Regimes in Coordinated Market Economies." Socio-Economic Review 7 (3), pp. $375^{-406 .}$

Cavalli, A., and O. Galland. 1995. Youth in Europe. London: Pinter.

Chevalier, T. 2016. "Varieties of Youth Welfare Citizenship. Towards a Two-Dimension Typology." Journal of European Social Policy 26, pp. 3-19. 
Dubois, H., and A. Ludwinek, eds. 2015. Access to Social Benefits: Reducing Non-Take-Up. Luxembourg: Publications Office of the European Commission.

Esping-Andersen, G. 1990. The Three Worlds of Welfare Capitalism. Princeton: Princeton University Press.

Estevez-Abe, M., T. Iversen, and D. Soskice. 2001. "Social Protection and the Formation of Skills: A Reinterpretation of the Welfare State." In Varieties of Capitalism, eds. P. A. Hall and D. Soskice. Oxford: Oxford University Press, $145^{-83}$.

Featherstone, K, and C.M. Radaelli, eds. 2003. The Politics of Europeanization. Oxford: Oxford Univ. Press.

Gallie, D., and S. Paugam. 200o. Welfare Regimes and the Experience of Unemployment in Europe. oup Oxford.

Gangl, M. 2001. "European Patterns of Labour Market Entry. A Dichotomy of Occupationalized vs. Non-Occupationalized Systems?" European Societies 3 (4), pp. 471-94.

Garritzmann, J. L. 2016. The Political Economy of Higher Education Finance. The Politics of Tuition Fees and Subsidies in OECD Countries, 1945-2015. London: Palgrave Macmillan.

Hadjivassiliou, K. P., A. Tassinari, W. Eichhorst, and F. Wozny. 2019. "How Does the Performance of School-to-Work Transition Regimes Vary in the European Union?" In Youth Labor in Transition, eds. J. O'Reilly et al. Oxford: Oxford University Press, 71-103.

Jones, G., and C. Wallace. 1992. Youth, Family, and Citizenship. Open University Press.

Jones, G. 2009. Youth. Cambridge: Polity.

Kalala-Mabuluki, E. and S. Siurala, 2019. “"Politiques Intégrées de Jeunesse " :Difficultés et Leviers d'action." Les cahiers de l'action (2), pp. 95-100.

Knijn, T. 2012. "New Social Risks for Young Adults: A Conceptual Framework." In Work, Family Policies and Transitions to Adulthood in Europe, Basingstoke: Palgrave Macmillan, 3-16.

Loncle, P. and C. Martin, La politisation des jeunes et le fonctionnement associatif: exemples de deux associations locales faiblement institutionnalisées. Revue Jeunes et Société, 4 (2), pp. 113-136.

Müller, W., and M. Gangl. 2003. Transitions from Education to Work in Europe: The Integration of Youth into EU Labour Markets. illustrated edition. OuP Oxford.

O'Reilly, J. et al., eds. 2019. Youth Labor in Transition. Inequalities, Mobility, and Policies in Europe. Oxford: Oxford University Press.

Pickard, S. and C. Van de Velde, 2021 (forthcoming). "Trois portraits de la colère chez les jeunes adultes." In T. Chevalier and P. Loncle (eds.), Une jeunesse sacrifiée?. Paris: PUF. 
Pohl, A., and A. Walther. 2007. "Activating the Disadvantaged. Variations in Addressing Youth Transitions across Europe." International Journal of Lifelong Education 26 (5), pp. 533-53.

Schild, H. 2013. 15 Years of Partnership between the European Commission and the Council of Europe in the Field of Youth: Past Achievements -Futureperspectives. Strasbourg: Youth partnership.

Third European Youth Work Convention. 2020. Final Declarationof the 3rd European Youth Work ConventionSignposts for the Future. Bonn.

Vial, B. 2020. "L'expérience Du Non-Recours Dans Les Parcours de Jeunes Peu Ou Pas Diplômés." Thèse pour l'obtention du doctorat en science politique. Université de Grenoble.

Wacquant, L. 2012. "Three Steps to a Historical Anthropology of Actually Existing Neoliberalism: a Historical Anthropology of Actually Existing Neoliberalism." Social Anthropology 2o(1), pp. 66-79.

Walther, A. 2006. "Regimes of Youth Transitions: Choice, Flexibility and Security in Young People's Experiences across Different European Contexts.” Young 14 (2), pp. 119-39.

Walther, A., J. Batsleer, P. Loncle, A. and Pohl, Young People and the Struggle for participation. Contested Practices, Power and Pedagogies in Public Spaces. London: Routledge, 2019.

Walther, A., D. G. Lüküslü, P. Loncle, and A. Pais. 2021. "Regimes of Youth Participation? Comparative Analysis of Youth Policies and Participation across European Cities." Young 29 (2), pp. 191-209.

Williamson, H. 2020. Cornerstone Challenges for European Youth Work and Youth Work in Europe Making the Connections and Bridging the Gaps. Bonn: 3rd European Youth Work Convention. 